\title{
11ß-Hydroxylase and aldosterone synthase expression in fetal rat hippocampal neurons
}

\author{
S M MacKenzie, M Lai ${ }^{1}$, C J Clark ${ }^{2}$, R Fraser, C E Gómez-Sánchez ${ }^{3}$, J R Seckl ${ }^{1}$, \\ J M C Connell and E Davies \\ Blood Pressure Group, Department of Medicine and Therapeutics, Western Infirmary, Church Street, Glasgow G11 6NT, UK \\ ${ }^{1}$ Molecular Endocrinology Laboratory, Endocrinology Unit, Molecular Medicine Centre, Western General Hospital, Edinburgh EH4 2XU, UK \\ ${ }^{2}$ Institute of Biomedical and Life Sciences, University of Glasgow, Glasgow G12 8QQ, UK \\ ${ }^{3}$ Endocrinology, G V Montgomery VA Hospital and University of Mississippi, Jackson, Mississippi 65201, USA
}

(Requests for offprints should be addressed to S M MacKenzie; Email: 9244731m@clinmed.gla.ac.uk)

\begin{abstract}
The central nervous system produces many of the enzymes responsible for corticosteroid synthesis. A model system to study the regulation of this local system would be valuable. Previously, we have shown that primary cultures of hippocampal neurons isolated from the fetal rat can perform the biochemical reactions associated with the enzymes 11ß-hydroxylase and aldosterone synthase. Here, we demonstrate directly that these enzymes are present within primary cultures of fetal rat hippocampal neurons.
\end{abstract}

Journal of Molecular Endocrinology (2002) 29, 319-325

\section{Introduction}

A considerable body of evidence has now accumulated to suggest that corticosteroid synthesis occurs in tissues other than the adrenal cortex, most notably the cardiovascular system and the central nervous system (CNS) (Strömstedt \& Waterman 1995, Gómez-Sánchez et al. 1996, Silvestre et al. 1998, Kayes-Wandover \& White 2000). The CYP11B1 gene encodes the $11 \beta$ hydroxylase enzyme while the highly homologous CYP11B2 gene encodes aldosterone synthase. We have shown that the rat brain transcribes both of these genes and that expression of the resulting corticosteroidogenic enzymes localises to the hippocampus and the cerebellum (MacKenzie et al. 2000a). In addition, work by Furukawa et al. (1998) has demonstrated that transcription of the genes for the side-chain cleavage enzyme (CYP11A1), 3 $\beta$ hydroxysteroid dehydrogenase, and the steroidogenic acute regulatory protein (StAR) localises to the same regions of the brain and have an identical distribution within those areas. These earlier studies did not confirm that there was active steroid synthesis as a consequence of this mRNA expression. However, we have recently shown that incubation of 11-deoxycorticosterone (DOG) with a primary culture of hippocampal neurons isolated from the fetal rat results in the production of corticosterone and aldosterone (MacKenzie et al. $2000 b$ ). This strongly suggests the presence of the $11 \beta$-hydroxylase and aldosterone synthase enzymes within these cells and, as such, would render them a valuable model for the study of neural corticosteroid production.

The aim of this study was to detect the presence of CYP11B1 and CYP11B2 transcripts in primary cultures of fetal hippocampal neurons by RT-PCR and immunocytochemistry, and to demonstrate that this transcription results in immunoreactive $11 \beta$-hydroxylase and aldosterone synthase. We also investigated the transcription of the CRP11A1, StAR and adrenodoxin genes within these cells. Adrenodoxin is a vital cofactor required by the cytochrome $\mathrm{P} 450$ enzymes in the pathway. The CYP11A1 gene encodes the side-chain cleavage enzyme which catalyses the initial conversion of cholesterol to pregnenolone, while StAR performs the rate-limiting step in corticosteroid synthesis, presenting cholesterol to the side-chain cleavage 
Table 1 Oligonucleotide primer sequences used for PCR amplification of cDNA

\begin{tabular}{|c|c|c|c|}
\hline & & Sequence $\left(5^{\prime}-3^{\prime}\right)$ & $\begin{array}{l}\text { Product length } \\
\text { (bp) }\end{array}$ \\
\hline \multicolumn{4}{|l|}{ Primer } \\
\hline CYP11B1/2 & $\begin{array}{l}\text { Sense } \\
\text { Antisense }\end{array}$ & $\begin{array}{l}\text { AAC TCC GTG GCC TGA GAC G } \\
\text { GCT GTG TGG TGG ACT TGA AC }\end{array}$ & 342 \\
\hline CYP11A1 & $\begin{array}{l}\text { Sense } \\
\text { Antisense }\end{array}$ & $\begin{array}{l}\text { CAA CAT CAC AGA GAT GCT GGC AGG } \\
\text { CTC AGG CAT CAG GAT GAG GTT GAA }\end{array}$ & 583 \\
\hline StAR & $\begin{array}{l}\text { Sense } \\
\text { Antisense }\end{array}$ & $\begin{array}{l}\text { TAC ATT CAA GCT GTG TGC TG } \\
\text { TTA CTT AGC ACT TCA TCT CC }\end{array}$ & 318 \\
\hline Andrenodoxin & $\begin{array}{l}\text { Sense } \\
\text { Antisense }\end{array}$ & $\begin{array}{l}\text { GAC TCT CTG CTA GAT GTT GTG ATT } \\
\text { ATT CTT GCT CAT GTC AAC AGA CTG TCG }\end{array}$ & 289 \\
\hline
\end{tabular}

enzyme (Arakane et al. 1998). The transcription of these genes would be a strong indication that these cells are capable of de novo corticosteroid synthesis from cholesterol.

\section{Materials and methods}

\section{Preparation of primary rat fetal hippocampal neuronal cultures}

Cultures were prepared from hippocampi dissected out of embryonic day 18 Wistar rats (Banker \& Goslin 1991). Tissue was washed three times in Hanks' balanced salt solution (Life Technologies) containing Hepes buffer, $\mathrm{pH} 7 \cdot 4$, and then trypsinised $(1 \mathrm{mg} / \mathrm{ml})$ for $10 \mathrm{~min}$ at $37^{\circ} \mathrm{C}$ and dissociated by trituration through a 25 gauge sterile needle. Cells were seeded at a density of $2 \times 10^{6}$ cells per six-well poly-L-lysine-coated tissue culture plate (Fred Baker Scientific, Runcorn, Cheshire, UK) or $4 \times 10^{5}$ cells per eight-well culture slide (Fred Baker Scientific) in neurobasal medium containing B27 growth supplement and $0.5 \mathrm{mM}$ L-glutamine and grown in a humidified incubator at $37^{\circ} \mathrm{C} / 5 \% \quad \mathrm{CO}_{2}$. The next day, cytosine arabinoside $(5 \mu \mathrm{M})$ (Sigma, Poole, Dorset, UK) was added to the medium to inhibit glial proliferation. Cells were left to grow for 7 days before experiments were performed. Cultures contained less than $5 \%$ glia as determined by immunocytochemical staining with glial fibrillary-associated protein antibody.

\section{RNA isolation}

Total RNA was extracted from cells grown on six-well plates (see above) or from adult female
Wistar-Kyoto rat tissue according to the RNAzol B reagent protocol (Biogenesis Ltd, Poole, Dorset, UK). The resulting RNA was DNase-treated using RQ1 DNase (Promega). The quality and concentration of the RNA was confirmed by spectrophotometry and electrophoresis on ethidium bromide-stained agarose gels.

\section{RT-PCR and Southern blotting}

Oligonucleotide primers (Oswel, Southampton, Hampshire, UK) homologous to parts of the CYP11B1/B2, CYP11A1, StAR and adrenodoxin genes were produced (Table 1). RT-PCR amplification was performed using the GeneAmp RNA PCR kit (Perkin Elmer, Warrington, Cheshire, UK) and oligo-dT primers. cDNA was transcribed according to the standard kit protocol. Amplification of CIP11A1 and adrenodoxin followed the method of Strömstedt \& Waterman (1995). Reactions had an initial $10 \mathrm{~min}$ denaturation step at $94^{\circ} \mathrm{C}$ followed by 35 cycles of $2 \mathrm{~min}$ denaturation at $94{ }^{\circ} \mathrm{C}, 1 \mathrm{~min}$ annealing at $55^{\circ} \mathrm{C}$ (except for CYP11B1/2 where it was $60^{\circ} \mathrm{C}$ ) and 2 min extension at $72{ }^{\circ} \mathrm{C}$. A final 7 min extension step at $72{ }^{\circ} \mathrm{C}$ was used in each reaction. Control reactions omitted reverse transcriptase or substituted water for RNA. Adrenodoxin RT-PGR products were visualised on ethidium bromidestained $2 \%$ agarose gels under u.v. light. All other RT-PCR products were visualised by Southern blotting to Hybond-N+ membrane (Amersham Pharmacia Biotech). Products were detected using ${ }^{32}$ P-labelled oligonucleotide probes (Oswel). The CYP11B1-specific oligonucleotide was 5'-TAA 
ACA TTG AGT CCA ATA-3' (bases 556-574, sense); the CYP11B2-specific oligonucleotide was 5'-TGG ATG TGG AGG AAA GTG-3' (bases 556-574, sense); the CYP11A1-specific oligonucleotide was 5'-GGT GGA GTG TGA GTG TGT CGT TGA TGG TGG CTT TGA G-3' (bases 1199-1163, antisense); the StAR-specific oligonucleotide was 5'-GCA TAG TCA ACA ACG AGG-3' (bases 319-336, sense).

\section{Monoclonal antibody preparation}

Synthetic peptides corresponding to hydrophilic areas of aldosterone synthase and $11 \beta$-hydroxylase exhibiting minimal homology were prepared by Research Genetics Inc. (Huntsville, AL, USA). The aldosterone synthase monoclonal antibody was generated by immunising CD-1 mice, as described by Tam (1988), with the multiple antigenic peptide MAP-KVRQNARGSLTMDVQQ corresponding to residues $175-190$. The $11 \beta$-hydroxylase monoclonal antibody was generated in SwissWebster mice immunised with the peptide KNVYRELAEGRQQS, corresponding to residues 272-285, conjugated to chicken serum albumin. The spleens of the mice with the highest titre were fused to an SP-2 myeloma cell line and the clones selected for their ability to bind immobilised sonicated zona glomerulosa mitochondria from rats on a low sodium diet. Both antibodies were of the IgG1 subclass. The specificity of these antibodies for their respective target enzymes has previously been established by immunostaining of rat adrenal tissue (MacKenzie et al. 2000a).

\section{Immunostaining of fetal rat hippocampal neurons}

Cells grown on eight-well culture slides (see above) were fixed for immunostaining by immersion in ice-cold acetone for $10 \mathrm{~min}$. Cells were rehydrated through graded ethanol, then rinsed in deionised water and Tris-buffered saline. Subsequent steps were performed using the Dako Catalysed Signal Amplification (CSA) System Peroxidase Kit (Dako Ltd, Cambridge, Cambridgeshire, UK). The cells were incubated with the primary antibody for $1 \mathrm{~h}$ at $4{ }^{\circ} \mathrm{C}$. Immunostaining was developed with 3,3'-diaminobenzidine tetrahydrochloride (Dako). Cells were then counterstained with filtered modified Harris haematoxylin solution (Sigma-
Aldrich Co. Ltd, Poole, Dorset, UK) for $5 \mathrm{~min}$, dehydrated and mounted in DPX (BDH Laboratory Supplies, Lutterworth, Leics, UK). Control sections were incubated with mouse IgG1 negative control culture supernatant (Dako). In addition, the specificity of the monoclonal antibodies was confirmed by incubating them with an excess of their respective antigenic polypeptides (Alta Bioscience, Birmingham, UK), thus quenching any antibody binding.

\section{Results}

\section{RT-PCR}

CYP11B1, CYP11B2, CYP11A1 and StAR transcripts were visible in adrenal gland, brain and fetal hippocampal neuron samples after Southern blotting (Fig. 1). Although semi-quantitative, it was apparent that each transcript was more abundant in adrenal tissue than in brain or fetal hippocampal neurons. Adrenodoxin transcripts were sufficiently abundant in adrenal gland, brain and fetal hippocampal neuron samples to be visible on an ethidium bromide-stained agarose gel under u.v. light. All control reactions were negative.

\section{Immunostaining}

Cells stained positively for 11ß-hydroxylase (Fig. 2a) and aldosterone synthase (Fig. 2b). Staining for both enzymes was apparent in the dendrites. Cells incubated with mouse IgGl as a negative control were unstained (Fig. 2c). Positive immunostaining was quenched by prior incubation of each antibody with an excess of its immunogenic peptide (data not shown).

\section{Discussion}

The CYP11B1 and CYP11B2 genes are transcribed within primary cultures of fetal rat hippocampal neurons and are subsequently translated to form immunoreactive 11 1 -hydroxylase and aldosterone synthase polypeptides. This complements our earlier finding that incubation of these cells with the enzymes' common substrate, DOG, results in the production of their respective products, corticosterone and aldosterone. 

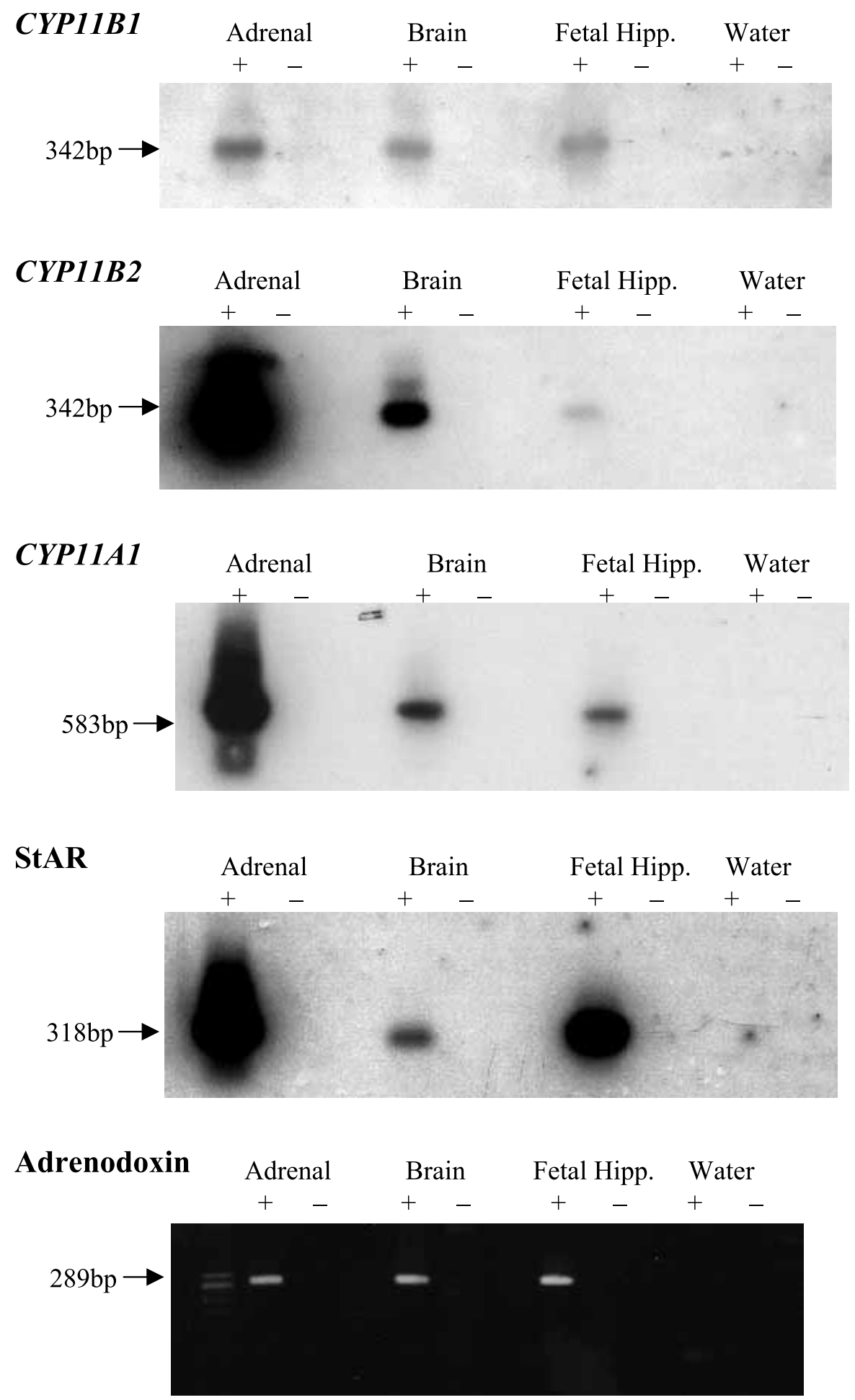

Figure 1 RT-PCR/Southern blotting results, in the presence (+) and absence (-) of reverse transcriptase. Hipp, hippocampus. 

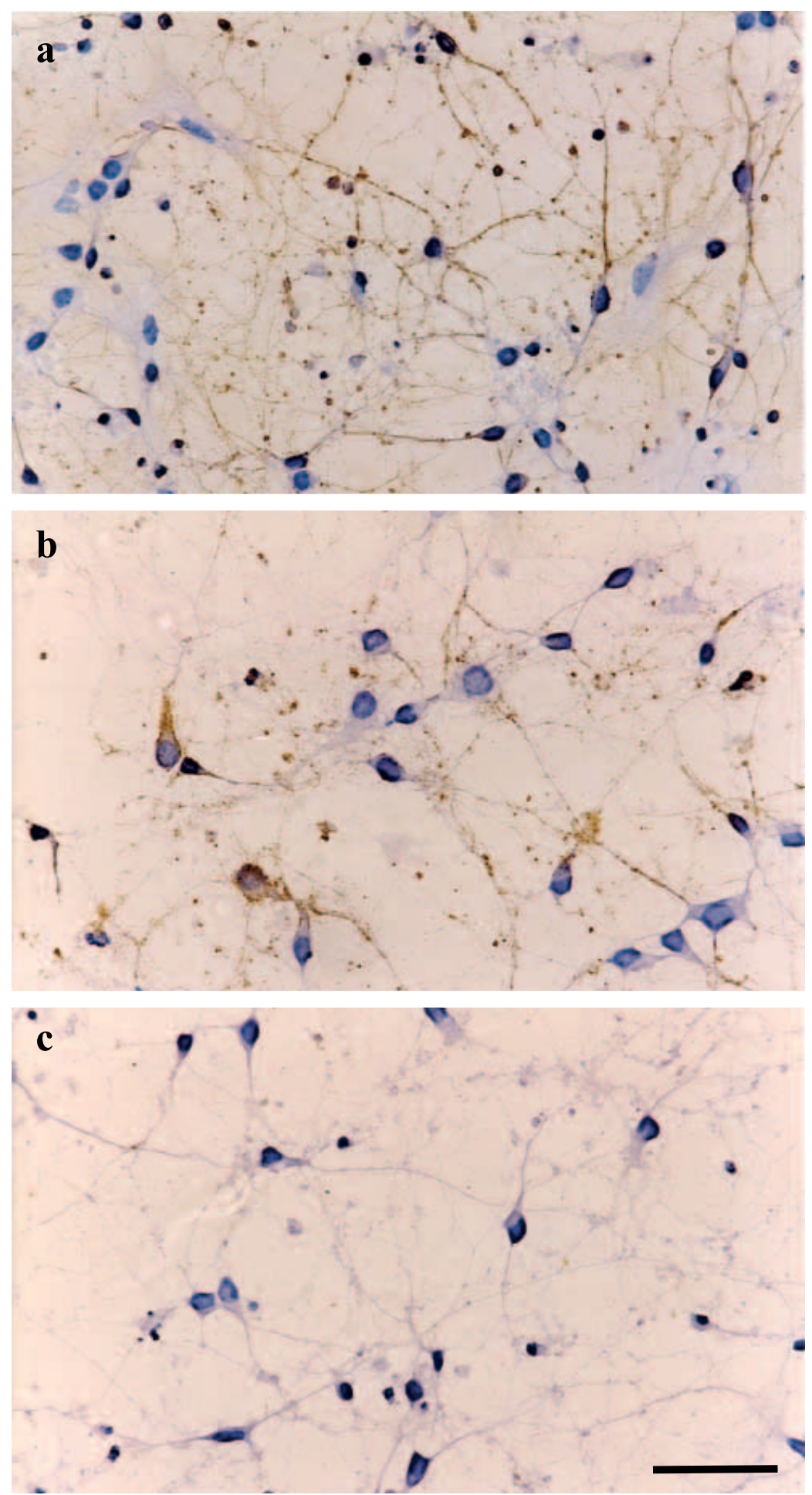

Figure 2 Immunostaining for steroidogenic enzymes in primary cultures of fetal rat hippocampal neurons. Staining for $11 \beta$-hydroxylase (a) and aldosterone synthase (b). (c) Mouse IgG1 negative control. Scale bar $=50 \mu \mathrm{m}$. 
We have also shown that the genes for the side-chain cleavage enzyme (CYP11A1), adrenodoxin and StAR are transcribed in primary cultures of fetal rat hippocampal neurons. The transcription of these genes suggests that primary cultures of fetal rat hippocampal neurons could be capable of $d e$ novo production of corticosteroids from cholesterol, as well as using circulating DOC as substrate.

We have previously shown that $11 \beta$-hydroxylase and aldosterone synthase are expressed in the adult rat hippocampus and cerebellum (MacKenzie et al. 2000a). Other components of the glucocorticoid and mineralocorticoid pathway localise to the same regions of the CNS (Furukawa et al. 1998). Moreover, their distributions correlate closely with that of the mineralocorticoid receptor (MR) in the brain (Agarwal et al. 1993). It is also apparent from these studies, and from others (Ukena et al. 1998, 1999), that all of these genes are expressed within the Purkinje neurons of the cerebellum, as the size of this cell makes expression relatively easy to detect. However, the present study is the first to show that hippocampal neurons have a similar capability. Therefore, we now know that neurons in both the hippocampus and cerebellum express the majority of genes required for both corticosterone and aldosterone synthesis.

It is not clear what the relative contributions of neuronal and glial cells might be to total CNS corticosteroid production. Cultures of glial cells are known to express the side-chain cleavage enzyme and $3 \beta$-hydroxysteroid dehydrogenase but $11 \beta$ hydroxylase could not be detected by RT-PCR (Jung-Testas et al. 1989, Mellon \& Deschepper 1993). CYP11B2 transcripts could not be detected in these cells by RNase protection assay, although this technique is less sensitive than RT-PGR. It remains possible that, unlike those enzymes acting earlier in the pathway, GNS expression of CYP11B1 and CYP11B2 does not take place in glia but rather in neurons. 11 $\beta$-Hydroxysteroid dehydrogenase type 2 is not expressed in the adult rat hippocampus (Robson et al. 1998) so active glucocorticoid is free to bind MR within this region. This means that any aldosterone produced as a result of hippocampal aldosterone synthase expression will have to compete with glucocorticoid for MR. The proportion of bound MR will, therefore, be determined by the combined levels of corticosterone and aldosterone, rather than of aldosterone alone.
There is little information on the regulation of expression of these genes in neurons, although it is possible that this differs from that described in adrenal cortex. Our own preliminary studies show that dietary sodium restriction can significantly upregulate CYP11B2 transcript levels in the rat hippocampus and cerebellum (Ye et al. 2002). Therefore, stimuli are capable of inducing predictable physiological responses from this system. The role of local corticosteroid production - as distinct from hormone availability from the systemic circulation or reactivation of dehydrocorticosterone by $11 \beta$-hydroxysteroid dehydrogenase type $1-$ remains to be determined. Although the absolute level of expression in the CNS is low, it is possible that high concentrations of steroids acting in the autocrine or paracrine mode are available as a result of neuronal synthesis. Low levels of corticosteroid in the GNS can be capable of significant physiological effects. Doses of aldosterone which have no effect when administered i.v. are capable of raising systemic blood pressure when given through the i.c.v. route (Gómez-Sánchez 1986).

The adrenal corticosteroids can, under different circumstances, have either protective or destructive effects on nerve cells (Sapolsky 1996, McEwen 1999). Obviously, local production of corticosteroids by these very cells could have significant implications for certain neurodegenerative processes. Likewise, further research is required into the effects of corticosteroids in the brain on memory and learning (Schumacher et al. 1997, Douma et al. 1998), neuronal excitability (Joels 1997) and blood pressure homeostasis (Gómez-Sánchez 1997). The great complexity of the brain, together with the highly specific regional distribution of the corticosteroidogenic machinery throughout the GNS, makes direct study difficult. Models of neuronal corticosteroid production are urgently required for further study. The primary culture of fetal rat hippocampal neurons will be a valuable aid in examining the regulation of local CNS corticosteroid synthesis.

\section{Acknowledgements}

This work was funded in part by the Wellcome Trust, Project Grant No. 060362 and MRC Programme Grant No. G9317119. 


\section{References}

Agarwal MK, Mirshahi F, Mirshahi M \& Rostene W 1993 Immunochemical detection of the mineralocorticoid receptor in rat brain. Neuroendocrinology 58 575-580.

Arakane F, Kallen CB, Watari H, Foster JA, Sepuri NBV, Pain D, Stayrook SE, Lewis M, Gerton GL \& Strauss JF III 1998 The mechanism of action of steroidogenic acute regulatory protein (StAR). Fournal of Biological Chemistry 273 16339-16345.

Banker G \& Goslin K 1991 Rat hippocampal neurons in low density culture. In Culturing Nerve Cells, pp 251-282. Eds G Banker \& K Goslin. Cambridge, MA: MIT Press.

Douma BK, Korte SM, Buwalda B, la Fleur SE, Bohus B \& Luiten PGM 1998 Repeated blockade of mineralocorticoid receptors, but not of glucocorticoid receptors impairs food rewarded spatial learning. Psychoneuroendocrinology 23 33-44.

Furukawa A, Miyatake A, Ohnishi T \& Ichikawa Y 1998 Steroidogenic acute regulatory protein (StAR) transcripts constitutively expressed in the adult rat central nervous system: colocalization of StAR, cytochrome P-450(SCG) (CYPX1A1), and $3 \beta$-hydroxysteroid dehydrogenase in the rat brain. Fournal of Neurochemistry 71 2231-2238.

Gómez-Sánchez CE, Zhou M, Cozza EN, Morita H, Eddleman FC \& Gómez-Sánchez EP 1996 Corticosteroid synthesis in the central nervous system. Endocrine Research 22 463-470.

Gómez-Sánchez EP 1986 Intracerebroventricular infusion of aldosterone induces hypertension in rats. Endocrinology 118 819-823.

Gómez-Sánchez EP 1997 Central hypertensive effects of aldosterone. Frontiers in Neuroendocrinology 18 440-462.

Joels M 1997 Steroid hormones and excitability in the mammalian brain. Frontiers in Neuroendocrinology 18 2-48.

Jung-Testas I, Hu ZY, Baulieu EE \& Robel P 1989 Neurosteroids: biosynthesis of pregnenolone and progesterone in primary cultures of rat glial cells. Endocrinology 125 2083-2091.

Kayes-Wandover KM \& White PC 2000 Steroidogenic enzyme gene expression in the human heart. Fournal of Clinical Endocrinology and Metabolism 85 2519-2525.

MacKenzie SM, Clark CJ, Fraser R, Gómez-Sánchez CE, Connell JMC \& Davies E $2000 a$ Expression of $11 \beta$-hydroxylase and aldosterone synthase genes in the rat brain. Fournal of Molecular Endocrinology 24 321-328.

MacKenzie SM, Clark CJ, Ingram MC, Lai M, Seckl JR, Gómez-Sánchez CE, Fraser R, Connell JMC \& Davies E 2000 b
Corticosteroid production by fetal rat hippocampal neurons. Endocrine Research 26 531-535.

McEwen BS 1999 Stress and hippocampal plasticity. Annual Review of Neuroscience 22 105-122.

Mellon SH \& Deschepper CF 1993 Neurosteroid biosynthesis: genes for adrenal steroidogenic enzymes are expressed in the brain. Brain Research 629 283-292.

Robson AC, Leckie CM, Seckl JR \& Holmes MC 1998 $11 \beta$-Hydroxysteroid dehydrogenase type 2 in the postnatal and adult rat brain. Molecular Brain Research 61 1-10.

Sapolsky RM 1996 Stress, glucocorticoids and damage to the nervous system: the current state of confusion. Stress 1 1-19.

Schumacher M, Guennon R, Robel P \& Baulieu EE 1997 Neurosteroids in the hippocampus: neuronal plasticity and memory. Stress 2 65-78.

Silvestre J-S, Robert V, Heymes C, Aupetit-Faisant B, Mouas C, Moalic J-M, Swynghedauw B \& Delcayre C 1998 Myocardial production of aldosterone and corticosterone in the rat. Fournal of Biological Chemistry 237 4883-4891.

Strömstedt M \& Waterman MR 1995 Messenger RNAs encoding steroidogenic enzymes are expressed in rodent brain. Molecular Brain Research 34 75-88.

Tam JP 1988 Synthetic peptide vaccine design: synthesis and properties of a high-density multiple antigenic peptide system. PNAS 85 5409-5413.

Ukena K, Usui M, Kohchi C \& Tsutsui K 1998 Cytochrome P450 side-chain cleavage enzyme in the cerebellar Purkinje neuron and its neonatal change in rats. Endocrinology 139 137-147.

Ukena K, Kohchi C \& Tsutsui K 1999 Expression and activation of $3 \beta$-hydroxysteroid dehydrogenase $/ \Delta^{5}-\Delta^{4}$-isomerase in the rat Purkinje neuron during neonatal life. Endocrinology 140 805-813.

Ye P, Kenyon CJ, MacKenzie SM, Fraser R, Connell JMC \& Davies E 2002 Quantification of 11ß-hydroxylase (CYP11B1) gene expression in the rat adrenal gland and central nervous system following dietary sodium manipulation. 7th Annual Meeting of the European Council for Blood Pressure and Cardiovascular Research, PE10.

Received 24 July 2002

Accepted 5 August 2002 